\title{
STUDENTŲ VERTYBINIŲ ORIENTACIJŲ YPATUMAI
}

\author{
Rosita Lekavičienè \\ Kauno technologijos universitetas, Kaunas, Lietuva
}

\begin{abstract}
Rosita Lekavičienė. Docentè socialinių mokslų (psichologijos) daktarè. Kauno technologijos universiteto Psichologijos katedros vedẻja. Mokslinių tyrimų kryptis - socialinė asmenybès psichologija, organizacijų psichologija.

\section{SANTRAUKA}

Šiuolaikinèje diskusijoje apie vertybiniu orientaciju prigimti ir pobūdi išsiskiria dvi kryptys: 1) vertybe traktuojama kaip nuoroda i tiksla ir ji iškyla prieš žmogu kaip tai, kas turi büti; 2) vertybè suprantama kaip realiai funkcionuojanti, t. y. kaip socialinio elgesio reguliatorius. Straipsnyje pristatomas empirinis tyrimas, kurio tikslas - nustatyti, ar vertybiu eiliškumo viršūnèje esančios individo vertybès yra aktyviai funkcionuojančios, ar, priešingai, yra siekiamybè, idealas, ,kažko trükumas“. Tiriamieji - 630 Lietuvos aukštuju mokyklu studentu. Tyrimui naudota R. Ullrich ir R. de Muynck (1998 d) metodika „Mano dabartiniu vertybiniu orientaciju anketa”. Nustatyta, kad studentu vertybiniai prioritetai yra ,, savęs realizacija ir nepriklausomybe “ $(M=2,16 ; \sigma=0,56)$, „pripažinimas ir pagyrimas “ $(M=2,09 ; \sigma=0,57)$, ,palankumas ir pagalba“ $(M=2,08 ; \sigma=0,56)$. Pastaroji vertybé dažniausiai ir realizuojama gyvenime $(M=1,89 ; \sigma=0,46)$. Studentams mažiausiai vertinga ,ramaus gyvenimo ir atsipalaidavimo“ vertybe $(M=1,42 ; \sigma=0,91)$ bei ,galejjimas valdyti ir turèti įtakos kitiems “ $(M=1,43 ; \sigma=0,83)$. Nustatyta statistiškai reikšminga teigiama koreliacija $(p=0,000)$ tarp visu vertybiu reikšmingumo tiriamajam ir tarp ta vertybę atitinkančio elgesio poreiškio dažnumo. Glaudžiausias ryšys tarp vertybès reikšmingumo ir ta vertybę atitinkančio elgesio poreiškio dažnumo užfiksuotas pagal „, Kontaktu ir bendravimo “, „, Valdžios ir įtakos “, „, Ramybès ir atsipalaidavimo “ skales (visi $\tau_{b}=0,42 ; p=0,000$ ). Taigi galima teigti, kad vertybés atlieka socialinio elgesio reguliatoriaus vaidmeni ir rodo ketinima veikti kurioje nors asmenybès socialinio aktyvumo srityje.
\end{abstract}

Raktažodžiai: vertybinès orientacijos, vertybiniai prioritetai, elgesys.

\section{IVADAS}

$\mathrm{V}$ ertybiu problematika yra labai plati, nes bet kuri žmogaus gyvenimo sfera (nuo pačių asmeniškiausių ir intymiausių iki bendriausių, globalių, socialinių) gali būti tiriama per vertybiu prizmę (Kublickiene ir Rapoportas, 1999). Tyrimus šioje srityje apsunkindavo (ir apsunkina) vertybès (vertybinès orientacijos) apibrèžimo problema ir apskritai abejonès dèl konstrukto empirinio gyvybingumo (Rauchfleisch, 1994; Rost, 1995). Psichologijos žodynuose vertybinè orientacija aiškinama kaip individo dorovinių, socialinių, politinių, estetinių nuostatu sistema, programuojanti visa žmogaus veikla, nulemianti svarbiausią elgesio krypti (Psichologijos žodynas, 1993; Краткий психологический словарь, 1985). Šiuolaikinèje diskusijoje apie vertybiniu orientacijų prigimti ir pobūdị išsiskiria dvi kryptys:

1. Vertybé traktuojama kaip nuoroda i tiksla ir ji iškyla prieš žmogu kaip tai, kas turi būti, o ne tai, kas yra. Vaizdumo dèlei tai gali būti palyginama su paprasčiausiais fiziologiniais 
poreikiais - kuo alkanesni esame, tuo maistas skanesnis, kuo labiau sušalę - tuo labiau džiugina kambario šiluma ir pan. Taigi vertybė individui tuo svarbesnè, kuo,,alkanesnis“ tos vertybès atžvilgiu yra individas.

2. Vertybė suprantama kaip realiai funkcio$n u o j a n t i$, t. y. kaip socialinio elgesio reguliatorius, kuris rodo ketinimą veikti kurioje nors asmenybès socialinio aktyvumo srityje. Taigi jei individui kažkas yra vertinga, tai tas „kažkas“ nuolat ir realizuojama.

Šiame straipsnyje pristatomas empirinis tyrimas, kurio objektas - studentų vertybinès orientacijos. Tyrimo tikslas - nustatyti, ar vertybiu eiliškumo viršūneje esančios individo vertybès yra aktyviai funkcionuojančios, t. y. ar jos yra aktyviai veikiančios, ,gyvos“, besireiškiančios kasdienejje veikloje, ar, priešingai, yra siekiamybè, idealas, „kažko trūkumas“. Buvo tiriami įvairiu Lietuvos universitetų studentai.

\section{Uždaviniai:}

1. Nustatyti studentų vertybinius prioritetus.

2. Ivertinti ryši tarp vertybès reikšmingumo tiriamajam ir tarp tą vertybę atitinkančio elgesio poreiškio dažnumo.

Kadangi tyrimo metu buvo naudota vokiečiu psichologu R. Ullrich ir R. de Muynck (1998 d) metodika, hipotezę formulavome pagal minètu autoriu pristatomus teorinius ir empirinius tyrinejjimus.

Hipotezė: vertybè pagal svarbos eiliškumą užima tuo aukštesnę vieta, kuo labiau individui jos „trūksta“. Kitaip tariant, žemesnius ịvertinimus dažnumo skalèje turètu gauti tos vertybès, kurios studentams yra reikšmingesnès, t. y. kurios gauna aukštesnius įvertinimus vertingumo skaleje.

\section{TYRIMO METODIKA}

Tiriamieji - Lietuvos aukštujų mokyklų (KTU, LŽŪU, KMU, LVA) II-IV kursų studentai. Ištirta 630 studentų — 423 moterys ir 197 vyrai. Tiriamujų amžius - nuo 18 iki 29 metų. Didžiaja imties dali (97\%) sudarẻ tiriamieji iki 23 metu amžiaus.

Tyrimo metodika. Vertybinių orientacijų tyrimui naudota R. Ullrich ir R. de Muynck (1998 d) „Mano dabartinių vertybinių orientacijų anketa“. Ji sudaryta iš septynių skalių VPR „Pripažinimas ir pagyrimas“, VKO „Kontaktai ir bendravimas“, VPA „Palankumas ir pagalba“, VDU „Didelès pajamos ir nuosavybė“, VSA, ,Savęs realizacija ir nepriklausomybe“, VVA „Valdžia ir itaka“, VRA „Ramybė ir atsipalaidavimas“, kurios savo ruožtu dar yra skaidomos i 6-10 smulkesnių punktų. Pavyzdžiui, skalè VVA „Valdžia ir įtaka“ susideda iš tokių punktų: būti teisiam; nurodinèti; igyvendinti savo valia; būti pranašesniam už kitus ir pan. Kiekviena punktą studentas turi izvertinti nuo -3 iki 3 balu pagal tai, kas jam gyvenime yra apskritai vertinga, nesiejant minimų vertybiu su konkrečiomis situacijomis. Paskui nuo 0 iki 3 vertinamas kiekvienas punktas pagal tai, kaip dažnai per pastaraji laikotarpi studentas taip elgèsi, tai patyre ar taip darè. Šios skalès atitinkamai ivardytos DPR, DKO, DPA, DDU, DSA, DVA, DRA.

Duomenų statistinè analizė atlikta panaudojus statistinès analizès sistemą SPSS for Windows (Калинин, 2002).

\section{REZULTATAI}

Panaudojus Kolmogorovo-Smirnovo kriteriju, pirmiausia patikrintos suderinamumo hipotezès: i̇verčiu skirstiniai pagal visus skaliu punktus VPR $(1,2,3, \ldots, 10)$, VKO $(1,2,3, \ldots$, 10), VPA $(1,2,3, \ldots, 10)$, VDU $(1,2,3, \ldots, 9)$, $\operatorname{VSA}(1,2,3, \ldots, 10), \operatorname{VVA}(1,2,3, \ldots, 6)$, VRA $(1,2,3, \ldots, 6)$, taip pat VID VPR, VID VKO, VID_VPA, VID_VDU, VID_VSA, VID_VVA, VID_VRA (čia santrumpa VID_ rodo, kad imamas atitinkamos skalès vidurkis) yra normalūs. Visos tikrintos hipotezès atmestos (visi $p<0,05$ ), t. y. visu i̇verčiu skalèse minèti skirstiniai nèra normalūs, todèl atliekant tolimesnius skaičiavimus buvo naudoti neparametriniai metodai. Patikrinus nepriklausomumo hipotezes, visos nulinès hipotezès buvo atmestos, t. y. statistiškai irodyta, kad $\operatorname{VPR}(1,2,3, \ldots, 10)$, VKO $(1,2,3, \ldots, 10)$, VPA $(1,2,3, \ldots, 10)$, VDU $(1,2,3,4,7,9)$, VSA $(1$, $2,3, \ldots, 10)$, VVA $(1,2,3, \ldots, 6), \operatorname{VRA}(1,2,3$, $\ldots, 6)$ ir atitinkami DPR $(1,2,3, \ldots, 10), \operatorname{DKO}(1$, $2,3, \ldots, 10)$, DPA $(1,2,3, \ldots, 10)$, DDU $(1,2,3$, $4,7,9)$, DSA $(1,2,3, \ldots, 10)$, DVA $(1,2,3, \ldots$, $6)$, DRA $(1,2,3, \ldots, 6)$ rodikliai yra priklausomi. Ta pati operacija atlikta ir su skalių vidurkių rodikliais (VID_): visos nulinès hipotezès buvo atmestos. Kitaip tariant, buvo irodyta VID_VPR, VID_VKO, VID_VPA, VID_VDU, VID_VSA, VID_VVA, VID_VRA ir atitinkamų VID_DPR, VID_DKO, VID_DPA, VID_DDU, VID_DSA, VID_DVA, VID_DRA rodikliu priklausomybè. Toliau analizuojant sąryšius buvo pasirinktas 


\begin{tabular}{|c|c|c|c|c|c|}
\hline VPR skalès punktai & $\mathrm{N}$ & $\begin{array}{c}\text { Vidurkis } \\
\text { (VPR) }\end{array}$ & $\begin{array}{l}\text { Standartinis } \\
\text { nuokrypis } \\
\text { (VPR) }\end{array}$ & $\begin{array}{c}\text { Vidurkis } \\
\text { (DPR) }\end{array}$ & $\begin{array}{l}\text { Standartinis } \\
\text { nuokrypis } \\
\text { (DPR) }\end{array}$ \\
\hline VPR 1 stropumas & 623 & 1,71 & 1,22 & 1,74 & 0,71 \\
\hline VPR 2 sumanumas & 623 & 2,43 & 0,74 & 1,87 & 0,63 \\
\hline VPR 3 atkaklios pastangos & 623 & 2,30 & 1,00 & 1,92 & 0,81 \\
\hline VPR 4 uolumas & 622 & 1,53 & 1,10 & 1,44 & 1,13 \\
\hline VPR 5 ištvermingas darbas & 621 & 1,89 & 1,27 & 1,77 & 0,88 \\
\hline VPR 6 dideli pasiekimai & 622 & 2,09 & 1,04 & 1,32 & 0,76 \\
\hline VPR 7 sèkmè & 623 & 2,43 & 0,91 & 1,75 & 0,74 \\
\hline VPR 8 garbè & 622 & 1,70 & 1,23 & 1,37 & 0,83 \\
\hline VPR 9 ištvermè & 622 & 2,40 & 0,88 & 1,94 & 0,80 \\
\hline VPR 10 gebejjimas igyvendinti & 622 & 2,45 & 0,82 & 1,83 & 0,75 \\
\hline
\end{tabular}

1 lentelè. Skalès „Pripažinimas ir pagyrimas" (VPR ir DPR) aprašomoji statistika

\begin{tabular}{|c|c|c|c|c|c|}
\hline VKO skalès punktai & $\mathrm{N}$ & $\begin{array}{c}\text { Vidurkis } \\
\text { (VKO) }\end{array}$ & $\begin{array}{c}\text { Standartinis } \\
\text { nuokrypis } \\
\text { (VKO) }\end{array}$ & $\begin{array}{c}\text { Vidurkis } \\
\text { (DKO) }\end{array}$ & $\begin{array}{l}\text { Standartinis } \\
\text { nuokrypis } \\
\text { (DKO) }\end{array}$ \\
\hline VKO 1 sutikti pažistamus & 622 & 1,99 & 0,92 & 2,33 & 0,71 \\
\hline VKO 2 lankyti renginius & 622 & 1,55 & 1,21 & 1,45 & 0,83 \\
\hline VKO 3 pažinti naujus žmones & 621 & 2,01 & 1,06 & 1,56 & 0,84 \\
\hline VKO 4 išeiti į viešumą & 622 & 1,61 & 1,40 & 1,60 & 0,94 \\
\hline VKO 5 gebėti pakviesti & 623 & 1,72 & 1,05 & 1,55 & 0,83 \\
\hline VKO 6 ką nors veikti & 621 & 2,38 & 0,88 & 2,45 & 0,68 \\
\hline VKO 7 kaupti naujus ispūdžius & 620 & 2,17 & 0,96 & 1,96 & 0,84 \\
\hline VKO 8 išlaikyti iniciatyvą & 623 & 1,76 & 1,18 & 1,61 & 0,77 \\
\hline VKO 9 mégti šurmulị ir įvairovę & 623 & 1,27 & 1,54 & 1,71 & 0,94 \\
\hline VKO 10 patirti nuotykius & 621 & 2,01 & 1,16 & 1,75 & 0,94 \\
\hline
\end{tabular}

\begin{tabular}{|l|c|c|c|c|c|}
\hline Rodikliai & $\mathrm{N}$ & $\begin{array}{c}\text { Vidurkis } \\
\text { (VPA) }\end{array}$ & $\begin{array}{c}\text { Standartinis } \\
\text { nuokrypis } \\
\text { (VPA) }\end{array}$ & $\begin{array}{c}\text { Vidurkis } \\
\text { (DPA) }\end{array}$ & $\begin{array}{c}\text { Standartinis } \\
\text { nuokrypis } \\
\text { (DPA) }\end{array}$ \\
\hline VPA 1 paguoda & 623 & 1,59 & 1,40 & 1,51 & 0,81 \\
\hline VPA 2 visokeriopas aprūpinimas & 623 & 1,64 & 1,29 & 1,47 & 0,86 \\
\hline VPA 3 globa & 621 & 1,19 & 1,41 & 1,37 & 0,90 \\
\hline VPA 4 saugumo jausmas & 622 & 2,43 & 0,84 & 1,86 & 0,85 \\
\hline VPA 5 demesys & 623 & 2,20 & 0,89 & 2,04 & 0,73 \\
\hline VPA 6 pasikalbejjimas & 623 & 2,26 & 1,03 & 2,30 & 0,74 \\
\hline VPA 7 kai klausia mano nuomonès & 622 & 1,95 & 0,92 & 1,97 & 0,70 \\
\hline VPA 8 kai aš patiriu švelnumą & 623 & 2,32 & 0,95 & 1,96 & 0,83 \\
\hline VPA 9 supratingumas & 622 & 2,53 & 0,69 & 2,01 & 0,72 \\
\hline VPA 10 draugiškumas & 623 & 2,69 & 0,61 & 2,40 & 0,65 \\
\hline
\end{tabular}

2 lentelè. Skalès „Kontaktai ir bendravimas" (VKO ir DKO) aprašomoji statistika

3 lentelè. Skalès „Palankumas ir pagalba" (VPA ir DPA) aprašomoji statistika

ranginès koreliacijos Kendalio tau- $b$ koeficientas, nes jis, mūsų požiūriu, šiuo atveju yra tinkamesnis nei Spirmeno koeficientas (Čekanavičius, Murauskas, $2001 \mathrm{a}, \mathrm{b})$.

Trumpai aptarsime gautus rezultatus pagal atskiras skales.

Skalè „Pripažinimas ir pagyrimas“. Kaip labai reikšmingas vertybes studentai nurodé asmeninių pastangų reikalaujančius dalykus gebejjimą igyvendinti, sumanumą, ištvermę, taip pat ir nuo individo nepriklausanti dalyką — sèkmę.
Santykiškai mažiau vertingais laikomi uolumas, stropumas ir garbė. Savo elgesiu studentai dažniausiai demonstruoja ištvermę, atkaklias pastangas ir savikritiškiausiai įvertina savo didelių pasiekimų gebėjimus (žr. 1 lent.).

Apskaičiavus Kendalio koreliacijos koeficientus tarp vertybės reikšmingumo ir tarp tą vertybę atitinkančio elgesio poreiškio dažnumo gauta, kad visi koeficientai buvo statistiškai reikšmingi ir igijo reikšmes nuo žemiausios tarp punkto VPR 7 $s \dot{e} k m \dot{e}$ ir $\operatorname{DPR} 7\left(\tau_{\mathrm{b}}=0,14 ; \mathrm{p}=0,000\right)-\mathrm{iki}$ 


\begin{tabular}{|c|c|c|c|c|c|c|}
\hline \multirow[t]{10}{*}{$\begin{array}{l}4 \text { lentelè. Skalès „Didelès pajamos } \\
\text { ir nuosavybe்“ (VDU ir DDU) ap- } \\
\text { rašomoji statistika }\end{array}$} & VDU skalès punktai & $\mathrm{N}$ & $\begin{array}{l}\text { Vidurkis } \\
\text { (VDU) }\end{array}$ & $\begin{array}{l}\text { Standartinis } \\
\text { nuokrypis } \\
\text { (VDU) }\end{array}$ & $\begin{array}{l}\text { Vidurkis } \\
\text { (DDU) }\end{array}$ & $\begin{array}{l}\text { Standartinis } \\
\text { nuokrypis } \\
\text { (DDU) }\end{array}$ \\
\hline & VDU 1 užsiimti išskirtiniu hobiu & 623 & 1,32 & 1,42 & 0,92 & 0,90 \\
\hline & $\begin{array}{l}\text { VDU } 2 \text { mėgautis visišku technikos } \\
\text { komfortu }\end{array}$ & 623 & 1,38 & 1,40 & 1,09 & 0,84 \\
\hline & $\begin{array}{l}\text { VDU } 3 \text { dažnai leisti sau nusipirkti nauju } \\
\text { drabužių }\end{array}$ & 622 & 1,39 & 1,36 & 1,10 & 0,77 \\
\hline & $\begin{array}{l}\text { VDU } 4 \text { keliaujant gyventi prabangiuose } \\
\text { viešbučiuose }\end{array}$ & 623 & 0,82 & 1,65 & 0,31 & 0,58 \\
\hline & VDU 5 igyti pastovų turtą & 623 & 2,16 & 1,05 & 0,62 & 0,78 \\
\hline & VDU 6 galèti pasistatyti namą & 623 & 1,93 & 1,21 & 0,21 & 0,55 \\
\hline & VDU 7 važinėti ištaigingu automobiliu & 623 & 1,34 & 1,40 & 0,45 & 0,74 \\
\hline & VDU 8 stilingai įsirengti būstą & 623 & 1,86 & 1,16 & 0,54 & 0,78 \\
\hline & VDU 9 plètoti verslą & 619 & 2,10 & 1,19 & 0,38 & 0,71 \\
\hline \multirow[t]{11}{*}{$\begin{array}{l}5 \text { lentelè. Skalès „Savęs realizacija } \\
\text { ir nepriklausomybè“ (VSA ir DSA) } \\
\text { aprašomoji statistika }\end{array}$} & VSA skalès punktai & $\mathrm{N}$ & $\begin{array}{l}\text { Vidurkis } \\
\text { (VSA) }\end{array}$ & $\begin{array}{c}\text { Standartinis } \\
\text { nuokrypis } \\
\text { (VSA) }\end{array}$ & $\begin{array}{l}\text { Vidurkis } \\
\text { (DSA) }\end{array}$ & $\begin{array}{l}\text { Standartinis } \\
\text { nuokrypis } \\
\text { (DSA) }\end{array}$ \\
\hline & VSA 1 realizuoti save & 622 & 2,35 & 0,91 & 1,56 & 0,76 \\
\hline & VSA 2 likti sau ištikimam & 623 & 2,43 & 0,79 & 2,12 & 0,76 \\
\hline & VSA 3 išsaugoti savigarbą & 623 & 2,65 & 0,64 & 2,32 & 0,67 \\
\hline & VSA 4 suteikti savo gyvenimui prasmę & 622 & 2,67 & 0,73 & 1,82 & 0,83 \\
\hline & VSA 5 priimti nepriklausomus sprendimus & 623 & 2,16 & 0,93 & 1,71 & 0,75 \\
\hline & VSA 6 neturèti sau ko prikaišioti & 623 & 1,47 & 1,51 & 1,25 & 0,81 \\
\hline & VSA 7 nenukrypti nuo savo ịsitikinimų & 621 & 1,78 & 1,16 & 1,72 & 0,76 \\
\hline & VSA 8 vykdyti savo pareigas & 622 & 2,21 & 0,94 & 2,05 & 0,71 \\
\hline & VSA 9 padèti laimèti teisybei & 623 & 2,06 & 1,02 & 1,55 & 0,83 \\
\hline & VSA 10 gyventi vardan ko nors išliekančio & 621 & 1,79 & 1,29 & 1,42 & 0,97 \\
\hline
\end{tabular}

aukščiausios tarp punkto VPR 8 garbe் ir DPR 8 $\left(\tau_{\mathrm{b}}=0,45 ; \mathrm{p}=0,000\right)$.

Skalė „Kontaktai ir bendravimas“. Labiausiai vertinami šios skalès punktai yra nuolatinè veikla ir naujų ispūdžių potyris. Nuolatinis veikimas, kaip ir pažistamų sutikimas, studentų yra įvertinti kaip dažniausiai patiriamos vertybès (žr. 2 lent.).

Šioje skalèje koreliacijos koeficientai yra didesni nei ankstesnejje: mažiausias ryšys pastebimas tarp VKO 1 susitikti pažistamus ir tarp atitinkamų dažnumo įverčių DKO $1\left(\tau_{\mathrm{b}}=0,33\right.$; $\mathrm{p}=0,000$ ), o didžiausia koreliacija užfiksuota tarp VKO 9 mégti šurmuli ir ívairovę ir atitinkamu iverčių DKO 9 (čia $\left.-\tau_{\mathrm{b}}=0,55 ; \mathrm{p}=0,000\right)$.

Skalė „Palankumas ir pagalba“. Studentu labiausiai vertinamas yra draugiškumas ir supratingumas. Beje, draugiškumas yra laikomas gana dažnai patiriama vertybe - pagal ši punktą dažnio iverčiai yra aukščiausi. Rečiausiai studentai patiria (arba demonstruoja kitų atžvilgiu) globą (žr. 3 lent.).

Šios skalès visi koreliacijos koeficientai tarp vertybès svarbumo ir jos poreiškio elgesyje yra reikšmingi ir svyruoja nedaug - nuo $\tau_{\mathrm{b}}=0,21$ $(\mathrm{p}=0,000)$ tarp punkto VPA 4 saugumo jausmas ir DPA 4 iki $\tau_{\mathrm{b}}=0,35(\mathrm{p}=0,000)$ tarp punkto VPA 1 paguoda ir DPA 1.

Skalè „Didelès pajamos ir nuosavybè“. Ši skalè išsiskiria ypač žemais dažnių vertinimais, t. y. studentai turi palyginti nedaug galimybių dažnai patirti šias vertybes - galèti pasistatyti namą, keliaujant gyventi prabangiuose viešbučiuose, plètoti versla. Tačiau būtent verslo plètrą ir pastovaus turto igijima jie laiko vertingiausiais dalykais, kai tuo tarpu gyvenimas prabangiuose viešbučiuose visiškai nesureikšminamas (žr. 4 lent.).

Skale išsiskiria iš kitų ir tuo, kad tik joje aptikti trys punktai, kuriuose vertybès vertingumo lygis ir „gavimo" dažnis nèra susiję. Kitaip tariant, nèra ryšio tarp VDU 5 igyti pastovu turta, VDU 6 galèti pasistatyti nama ir VDU 8 stilingai isirengti būsta bei atitinkamų dažnio įverčių. Glaudžiausias ryšys fiksuojamas tarp VDU 1 užsiimti išskirtiniu hobiu ir DDU $1\left(\tau_{\mathrm{b}}=0,40 ; \mathrm{p}=0,000\right)$, o silpniausias tarp VDU 7 važinèti ištaigingu automobiliu ir DDU $7\left(\tau_{\mathrm{b}}=0,14 ; \mathrm{p}=0,000\right)$.

Skalė „Savęs realizacija ir nepriklausomybe்“. Ypač aukštus įverčius šioje skaleje gauna noras 


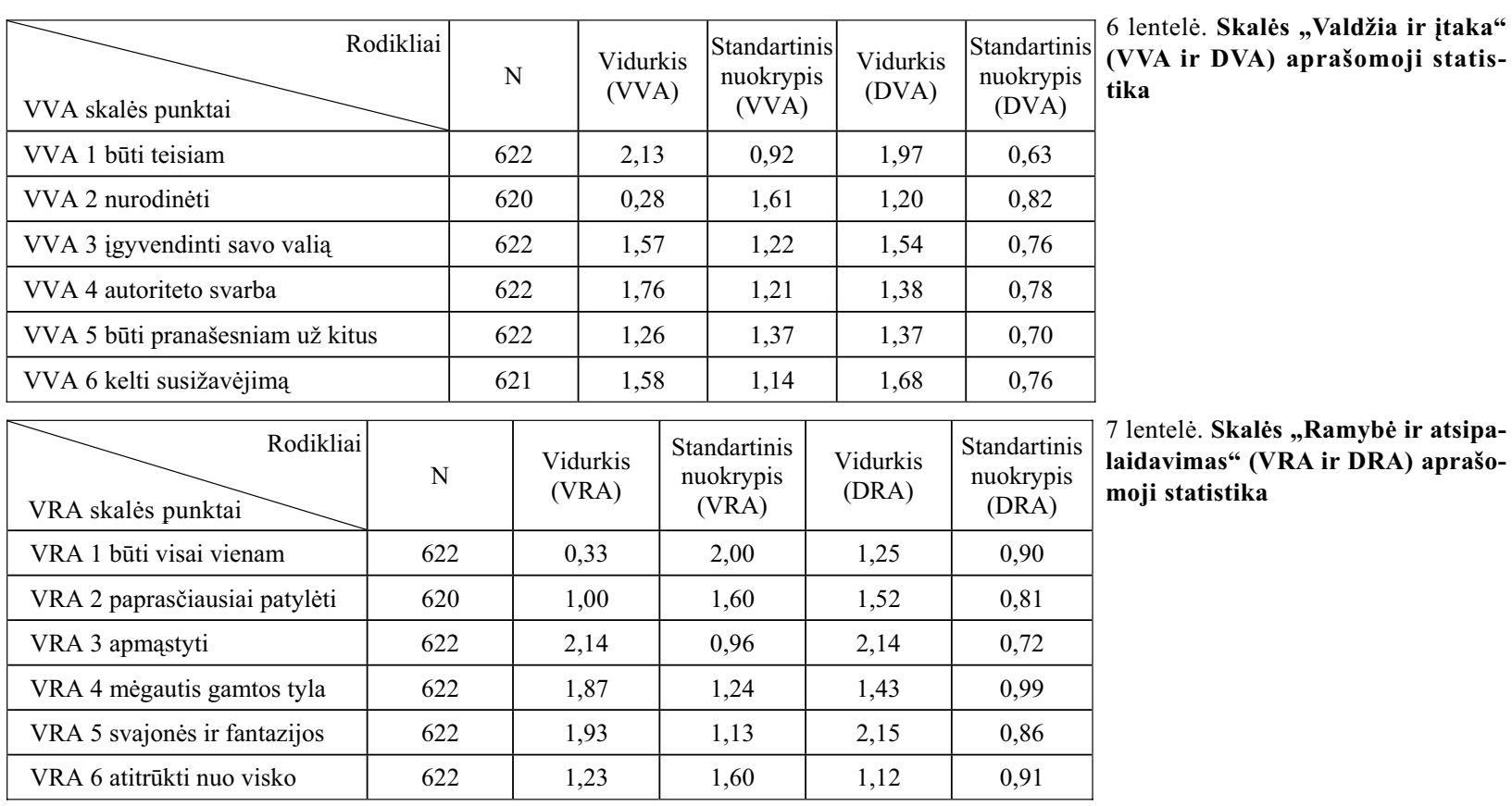

suteikti savo gyvenimui prasmę ir išsaugoti savigarbą. Pastaroji vertybe ir dažnių skalèje gauna didžiausius íverčius, t. y. studentai tai neretai demonstruoja realiame gyvenime, kaip kad ir buvimą ištikimam sau bei savo pareigų vykdymą. Rami sąžinè - neturejjimas sau ko prikaišioti gauna žemiausius įverčius ir pagal svarbuma, ir pagal poreiškio dažnumą (žr. 5 lent.).

Skalèje gana dideli koreliacijos koeficientai pastebimi pagal punktus VSA 10 gyventi vardan ko nors išliekančio $\left(\tau_{\mathrm{b}}=0,45 ; \mathrm{p}=0,000\right)$, VSA 9 padéti laimeti teisybei $\left(\tau_{\mathrm{b}}=0,42 ; \mathrm{p}=0,000\right)$ ir VSA 3 išsangoti savigarba $\left(\tau_{\mathrm{b}}=0,40 ; \mathrm{p}=0,000\right)$, o žemiausias - pagal punktą VSA 6 neturèti sau ko prikaišioti $\left(\tau_{\mathrm{b}}=0,18 ; \mathrm{p}=0,000\right)$.

Skalè „Valdžia ir įtaka“. Studentams pagal šią skalę yra vertingiausia būti teisiems (dažniu skalejje taip pat aukščiausi ivverčiai), tačiau tai nesusiję su galejjimu nurodinèti - pastarasis punktas gauna žemiausius iverčius tiek pagal vertinguma, tiek pagal tokio elgesio poreiškio dažnumą (žr. 6 lent.).

Šioje skaleje iš šešių jos punktų net pagal keturis pastebima gana aukšta (didesnè nei 0,4 ) koreliacija, pavyzdžiui, VVA 5 būti pranašesniam už kitus $\left(\tau_{\mathrm{b}}=0,46 ; \mathrm{p}=0,000\right)$, VVA 2 nurodinèti $\left(\tau_{\mathrm{b}}=0,45 ; \mathrm{p}=0,000\right)$ ir pan. Silpniausias ryšys tarp VVA 1 büti teisiam ir DVA $1\left(\tau_{\mathrm{b}}=0,28\right.$; $\mathrm{p}=0,000)$.

Skalė „Ramybė ir atsipalaidavimas“. Mažiausiai vertinga studentams atrodo būti visiškai vieniems (tačiau čia ypač didelis standartinis nuokrypis), nors įvertis išlieka teigiamas. Vertin- giausia studentams - galèjimas apmąstyti. Tai, kaip ir svajojimas bei fantazavimas, dažniausiai pasireiškia kasdieniame gyvenime (žr. 7 lent.).

Beje, šioje skalèje atrasta daugiausia stipriu koreliacijų pagal visus punktus. Mažiausias reikšmes igijo koeficientai pagal punktus VRA 2 paprasčiausiai patylèti $\left(\tau_{\mathrm{b}}=0,43 ; \mathrm{p}=0,000\right)$ ir VRA 3 apmastyti $\left(\tau_{\mathrm{b}}=0,43 ; \mathrm{p}=0,000\right)$, o didžiausią - pagal punktą VRA 5 svajonès ir fantazijos $\left(\tau_{\mathrm{b}}=0,53 ; \mathrm{p}=0,000\right)$.

\section{REZULTATUQ APTARIMAS}

Apibendrinus duomenis pagal skales matyti, kad vertingiausios studentams yra savęs realizacijos ir nepriklausomybès vertybès $(\mathrm{M}=2,16 ; \sigma=0,56)$, taip pat jiems svarbus yra pripažinimas ir pagyrimas $(\mathrm{M}=2,09 ; \sigma=0,57)$, palankumas ir pagalba $(\mathrm{M}=2,08 ; \sigma=0,56)$. Pastaroji vertybè dažniausiai ir realizuojama gyvenime $(\mathrm{M}=1,89 ; \sigma=0,46)$. Studentams mažiausiai vertingas ramus gyvenimas $(\mathrm{M}=1,42$; $\sigma=0,91)$ bei galejjimas valdyti ir turejjimas itakos kitiems ( $M=1,43 ; \sigma=0,83)$ (žr. 8 lent.).

R. Ullrich ir R. de Muynck (1998 a, b, c) teigi$\mathrm{mu}$, prioriteto teikimas pripažinimo bei pagyrimo vertybèms gali rodyti, kad individas turi atmetimo baimių, kad norima apsidrausti prieš egzistencijos baimes. Realiame gyvenime, kaip nurodo autoriai, nesėkmingai susiklosčius asmeniniam gyvenimui, santykiams su artimaisiais, profesinis darbas neretai tampa ta sritimi, kurioje ieškoma pripažinimo ir garbès. Jų nuomone, jei artimumo 


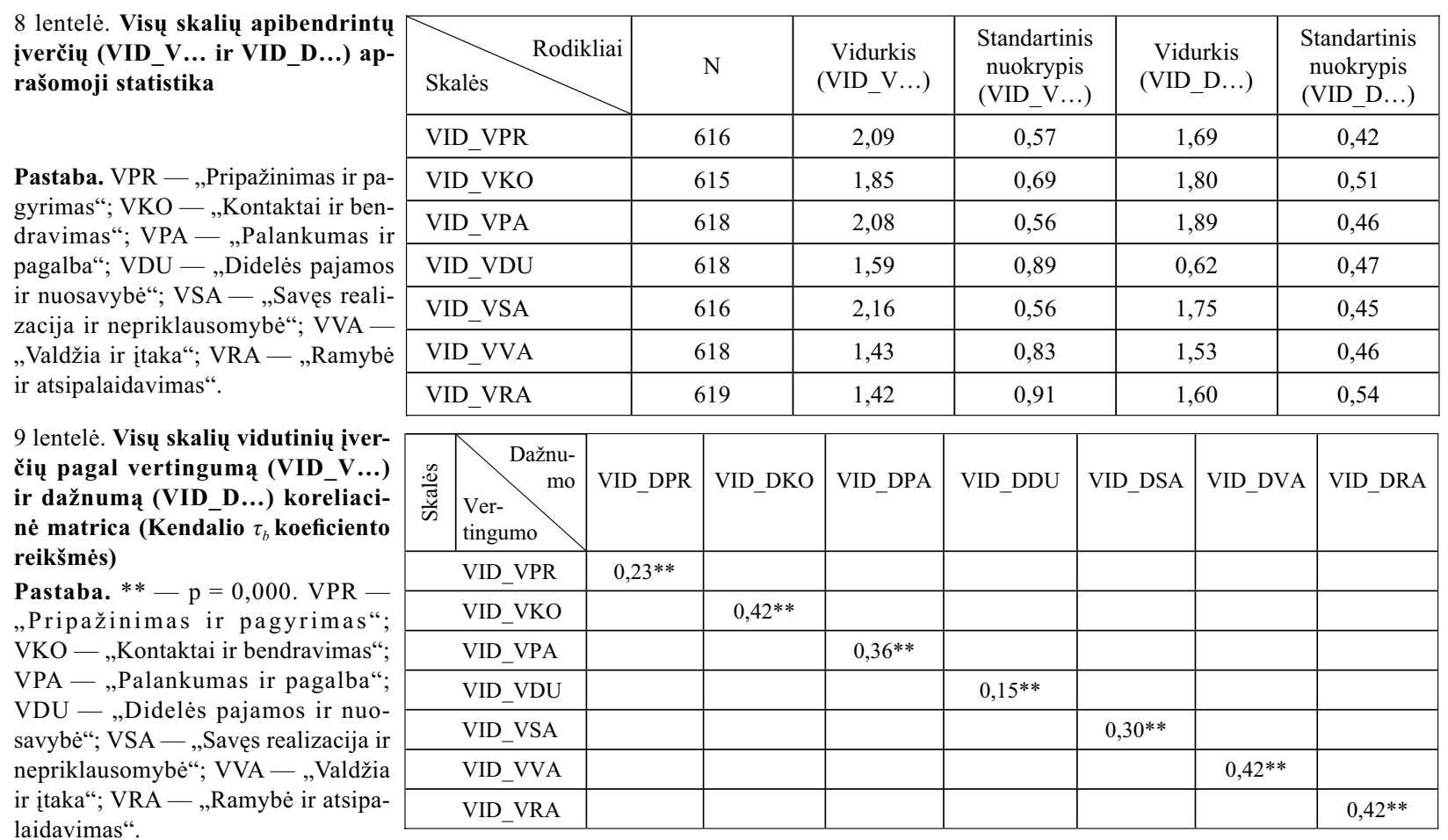

ir prièmimo, pripažinimo vertybès yra eiliškumo pagal svarbą viršuje, t. y. pirminès, tai individas dažniausiai būna išmokęs tam tikrų strategijų, kurios garantuoja tų vertybių realizaciją. Anot autorių, šiuo atveju neretai pastebimas tokių nuostatų prisilaikymas: „Kad būčiau mėgstamas, visada privalau tenkinti visus lūkesčius, kad būčiau pripažintas - turiu panaudoti kitus" ir pan. Šios nuostatos kartu rodo individo baimę būti nepakankamai šauniu ir todèl - atmestu, nepripažintu. Kai gynybinè strategija „kaip išvengti atmetimo" ima viršu prieš pozityvią strategija „kaip pasiekti pripažinimą“, krinta asmenybès savivertè ir teigiamos pasekmès nebeveda prie savęs įtvirtinimo ir savivertès pakèlimo. Autoriai pastebi, kad pripažinimo, artumo siekimas, kai naudojama tiek pozityvi, tiek gynybinè strategija, dažnai turi tas pačias šaknis - kitu akceptacijos trūkumą. Kartais reikia keisti ne tik gynybinę individo strategija, bet ir pozityviaja (pvz., kai yra akivaizdus atmetimas, individas nepajunta jokio diskomforto, nes atmetantysis jam buvo visai nesvarbus).

Idomu pažymėti, kad pastebimas tam tikras skirtumas tarp mūsų gautų duomenų ir tų, kuriuos ketvirtame dešimtmetyje tirdamas suaugusius žmones gavo H. A. Murray (Jarwinen, Nicholls, 1996): atsiskleidimo vertybė (mūsų tyrime tai atitiktu aukščiausiai vertintą savęs realizacijos ir nepriklausomybès vertybę) buvo ketvirta pagal svarbą, o svarbiausiomis ivardytos buvimo priimtam ir dominavimo vertybès. Vertybiniu orientacijų transformacija kintant kartoms bei visuomenés permainu laikotarpiu patvirtino ir V. Liubinienès ir M. L. Sanden (1997) atlikti tyrimai. C. A. Hill (1987) analizavo studentu socialines vertybes ir kaip svarbiausias nurodè emocine parama, pozityvu stimuliavima, kitu dèmesinguma. Minètos vertybès yra artimos mūsų tyrimo pripažinimo ir pagyrimo, palankumo ir pagalbos vertybems.

9 lentelèje pateikti duomenys rodo, kad nepasitvirtino kelta hipotezé, t. y. buvo gauti priešingi rezultatai: kylant įverčiams pagal vertybès reikšmingumą, kyla ir tą vertybę atitinkančio elgesio dažnumo îverčiai (visos koreliacijos teigiamos ir statistiškai reikšmingos). Glaudžiausi ryšiai tarp vertybinių orientacijų reikšmingumo ir vertybę atitinkančio elgesio poreiškio dažnumo yra užfiksuoti pagal „Kontaktų ir bendravimo“, „Valdžios ir itakos“, „Ramybès ir atsipalaidavimo“ skales (visi $\left.\tau_{\mathrm{b}}=0,42 ; \mathrm{p}=0,000\right)$ (žr. 9 lent.).

Galima numanyti, kad pakankamai aukštą koreliacija pagal „Kontaktu ir bendravimo“ bei „Ramybès ir atsipalaidavimo" skales lèmé tos aplinkybès, kad šias vertybes atitinkantis elgesys gali būti individo realizuojamas savarankiškai, nepriklausomai nuo aplinkiniu — tai, kas vertinga, galima ,paimti“ nepatiriant ypatingu trukdžių: pvz., „Kontaktų ir bendravimo“ 
skalejje - sutikti pažįstamus, lankyti renginius, išeiti i̇ viešuma, ką nors veikti ir pan.; „Ramybès ir atsipalaidavimo" - apmąstyti, mègautis gamtos tyla, svajoti, fantazuoti ir pan. Tuo pačiu principu turbūt negalima paaiškinti aukštos koreliacijos pagal „Valdžios ir įtakos“ skalę, kadangi šią vertybę realizuojantis elgesys numato glaudesnę individo sąveiką su aplinkiniais, didesnę tarpusavio priklausomybę. Tikètina, kad aukšta koreliacija gali būti užfiksuota dèl dviejų priežasčių: pirma, kadangi vidutinis įvertis šioje skalèje mažas, t. y. „Valdžios ir itakos“ vertybe nèra ypač reikšminga, todèl ir nesiekiama jos realizavimo gyvenime; antra, valdyti ir turèti įtakos kitiems žmonėms geba tik nedaugelis, todèl negalèdami to pasiekti gyvenime individai ima demonstruoti gynybišką elgesi - nuvertina minètą vertybę. Šitaip išsaugoma ir savo saviverte. Lengviau paaiškinti žemą koreliaciją tarp „Didelių pajamų ir nuosavybès" vertybès bei jos dažnumo įverčiu $\left(\tau_{\mathrm{b}}=0,15 ; \mathrm{p}=0,000\right)$. Objektyvios aplinkybès (tiriamieji dar yra studentai ir daugeliu atveju neužsidirba pragyvenimui, taip pat ekonominè Lietuvos situacija) lemia tai, kad tiriamieji nepažeisdami savo savivertès gali „prisipažinti“ retokai realizuojantys savo elgesiu šią vertybę $(\mathrm{M}=0,62 ; \sigma=0,47)$. Antra vertus, šioje skalejje net pagal tris punktus neaptikta koreliaciju tarp vertingumo ir elgesio poreiškio dažnumo (tai buvo aptarta jau anksčiau), t. y. studentu požiūris „Didelių pajamų ir nuosavybès“ vertybę ir galimybes tai realizuoti gyvenime yra išties nevienalytis. K. M. Sheldon, T. Kasser (1998) ir Sh. Oishi, E. Diener, E. Suh (1999) tyrimai parodè, kad gera individų savijauta yra susijusi su tuo, kaip sèkmingai yra realizuojamos individo vertybès ir tikslai gyvenime. Kad individo vertybès yra realiai funkcionuojančios, t. y. veikia kaip socialinio elgesio reguliatoriai, irodè ir I. Altun (2003), atlikęs sprendimų kokybès ir vertybiu saryšiu tyrimus, B. Verplanken, R. W. Holland (2002), tyrinèję elgesio ir vertybių ryšius, D. Beu, M. R. Buckley (2004), analizavę analogiškus klausimus organizacijų kontekste ir kt.

\section{IŠVADOS}

1. Tirtų studentų vertybiniai prioritetai yra savęs realizacija ir nepriklausomybe $(\mathrm{M}=2,16$; $\sigma=0,56)$, pripažinimas ir pagyrimas $(\mathrm{M}=2,09$; $\sigma=0,57)$, palankumas ir pagalba $(\mathrm{M}=2,08$; $\sigma=0,56)$. Pastaroji vertybè yra ir dažniausiai realizuojama gyvenime $(\mathrm{M}=1,89 ; \sigma=0,46)$. Studentams mažiausiai vertinga ramaus gyvenimo ir atsipalaidavimo vertybè $(\mathrm{M}=1,42$; $\sigma=0,91)$ bei galejimas valdyti ir turéti itakos kitiems $(\mathrm{M}=1,43 ; \sigma=0,83)$.

2. Nustatyta statistiškai reikšminga teigiama koreliacija $(p=0,000)$ tarp visų vertybių reikšmingumo tiriamajam ir tarp tą vertybę atitinkančio elgesio poreiškio dažnumo. Glaudžiausias ryšys tarp vertybės reikšmingumo ir tą vertybę atitinkančio elgesio poreiškio dažnumo užfiksuotas pagal „Kontaktų ir bendravimo“, „Valdžios ir itakos“, „Ramybès ir atsipalaidavimo“ skales (visi $\tau_{\mathrm{b}}=0,42 ; \mathrm{p}=0,000$ ). Taigi galima teigti, kad vertybès atlieka socialinio elgesio reguliatoriaus vaidmeni ir rodo ketinimą veikti kurioje nors asmenybès socialinio aktyvumo srityje.

\section{LITERATŪRA}

Altun, I. (2003). The perceived problem solving ability and values of student nurses and midwives. Nurse Education Today, 23 (8), 575-584.

Beu, D., Buckley, M. R. (2004). Using accountability to create a more ethical climate. Human Resource Management Review, 14 (1), 67-83.

Čekanavičius, V., Murauskas, V. (2001 a). Statistika ir jos taikymai. T. I. Vilnius: TEV.

Čekanavičius, V., Murauskas, V. (2001 b). Statistika ir jos taikymai. T. II. Vilnius: TEV.

Hill, C. A. (1987). Affiliation motivation: People who need people ... but in different ways. Journal of Personality and Social Psychology, 52, 1008-1018.

Jarwinen, D. W., Nichols, J. G. (1996). Adolescent's social goals, beliefs about the causes of social success and satisfactions in peer relations. Developmental Psychology, 32 (3), 435-441.

Kublickienè, L., Rapoportas, S. (1999). Vertybiniai konfliktai: socialinis psichologinis aspektas. A. Mitrikas (red.), Vertybès permainu metais. Vilnius: Lietuvos filosofijos ir sociologijos institutas.

Liubinienè, V., Sanden, M. L. (1997). Vertybinių prioritetų kaita Lietuvoje. Socialiniai mokslai. Sociologija, 1 (10), $32-36$.

Oishi, Sh., Diener, E., Suh, E. (1999). Value as a moderator in subjective well-being. Journal of Personality, 67 (1), 157-184.

Psichologijos žodynas. (1993). Vilnius: Mokslo ir enciklopedijų leidykla.

Rauchfleisch, U. (1994). Testpsychologie (3. Aufl.). 
Gottingen: Vandenhoeck und Ruprecht.

Rost, J. (1995). Lehrbuch Testtheorie und Testkonstruktion. Bern: Hans Huber.

Sheldon, K. M., Kasser, T. (1998). Pursuing personal goals: Skills enable progress, but not all progress is beneficial. Personality and Social Psychology Bulletin, 24 (12), 1319-1331.

Ullrich, R. \& De Muynck, R. (1998 a). ATP 1: Einübung von Selbstvertrauen - Bedingungen ind Formen Sozialer Schwierigkeiten. München: J. Pfeiffer Verlag.

Ullrich, R. \& De Muynck, R. (1998 b). ATP 2: Einübung von Selbstvertrauen - Grundkurs. München: J. Pfeiffer Verlag.

Ullrich, R. \& De Muynck, R. (1998 c). ATP 3: Einübung von Selbstvertrauen und Kommunikative Problemlösung Anwendung in Freundeskreis, Arbeit und Familie. München: J. Pfeiffer Verlag.

Ullrich, R. \& De Muynck, R. (1998 d). ATP: Testmappe. München: J. Pfeiffer Verlag.

Verplanken, B., Holland, R. W. (2002). Motivated decision making: Effects of activation and self-centrality of values on choices and behavior. Journal of Personality and Social Psychology, 82 (3), 434-447.

Калинин, С. И. (2002). Компьютерная обработка данных для психологов. Санкт-Петербург: Речь.

Краткий психологический словарь. (1985). Ред. Л. А. Карпенко и др. Москва: Политиздат.

\title{
FEATURES OF STUDENTS' VALUE ORIENTATION
}

\author{
Rosita Lekavičienè \\ Kaunas University of Technology, Kaunas, Lithuania
}

\begin{abstract}
In a modern discussion about the nature of value orientation and character two trends may be separated: 1) value is treated like a reference to a purpose and it rises against the human like it has to be, 2) value is understood like it operates in a particular way, i. e. like a regulator of social behavior. An empirical research is presented in the article. Its purpose was to define if the values of an individual, which are on the top of value hierarchy, function in an active way, or, on the contrary, an ambition, ideal, "lack of something". The students of Lithuania's high schools were investigated. A method of the questionnaire "My Contemporary Value Orientation" by R. Ullrich and R. De Muynck (1998 d) was used during the research. It was estimated, that students' value priority is implementation of oneself and independence $(\mathrm{M}=2.16 ; \sigma=0.56)$, appreciation and commendation $(\mathrm{M}=2.09 ; \sigma=0.57)$, acceptance and contribution $(\mathrm{M}=2.08 ; \sigma=0.56)$. The last-mentioned value is the most often implemented in life $(\mathrm{M}=1.89 ; \sigma=0.46)$. The value of quiet life and relaxation is the least valuable $(\mathrm{M}=1.42 ; \sigma=0.91)$ as well as the ability to influence and rule over others $(\mathrm{M}=1.43 ; \sigma=0.83)$. There were identified statistically significant positive correlations $(\mathrm{p}=0,000)$ between the importance of all values to the investigated and the frequency of behavior which conforms that value. The closest connection between value importance and the frequency of behavior manifestation was registered under the scales of contact and communication, authority and influence, tranquility and relaxation (all $\tau_{\mathrm{b}}=0.42 ; \mathrm{p}=0.000$ ). It is true to claim that the role of social behavior regulator is performed by values and it shows an intention to some social activity of an individual.
\end{abstract}

Keywords: value orientation, value priorities, behaviour.

Gauta $2005 \mathrm{~m}$. balandžio $9 \mathrm{~d}$.

Received on April 9, 2005

Priimta $2005 \mathrm{~m}$. birželio $30 \mathrm{~d}$.

Accepted on June 30, 2005
Rosita Lekavičienè

Kauno technologijos universitetas

(Kaunas University of Technology)

Donelaičio g. 20, LT-44239 Kaunas

Lietuva (Lithuania)

Tel +370 37300128

E-mail Rosita.Lekaviciene@ktu.lt 